\title{
GRAVITY AND MAGNETOTELLURIC INTERPRETATION OF THE SOUTHERN PART OF THE FOSSA MAGNA REGION, CENTRAL JAPAN
}

\author{
Susumu Nishimura, ${ }^{*}$ Jun'ichi Nishida, ${ }^{* *}$ and Tohru MogI*** \\ * Faculty of Science, Kyoto University, Kyoto, Japan \\ ** Otani University, Kyoto, Japan \\ *** Faculty of Engineering, Kyushu University, Fukuoka, Japan \\ (Received September 11, 1985; Revised April 28, 1986)
}

The results from recent east-west gravity and magnetotelluric traverse across the Fuji River, Central Japan, show that (i) extremely low Bouguer anomalies are distributed along the Fuji River and characterized with a strong horizontal gradient $4.5 \mathrm{mgal} / \mathrm{km}$, and (ii) a low-resistivity zone appears along the Fuji River.

The profile of density distribution was computed. From the results, it is seen that the sedimentary basin in this section has a steep slope beginning from the eastern part of the surveyed area and continuing even under the Itoigawa-Shizuoka Tectonic Line. The high-conductivity and low-density zone, whose density is smaller than $2.3 \mathrm{~g} / \mathrm{cm}^{3}$, has a width of $1.5-2.0 \mathrm{~km}$. These zones are possibly caused by the fracturing of rocks due to fault activity.

\section{Introduction}

The main geologic terrains of Honshu Island bend sharply to form a cusp at Fossa Magna, Central Japan. This will be discussed in relation to the collision of the Izu-Block of the Izu-Bonin Arc with Honshu, where the Izu-Bonin Arc joins with it (KOBAYASHI, 1941; EHARA, 1953). These ideas have been followed by recent analyses from the plate tectonics viewpoint (MATSUDA and UYEDA, 1971).

KAIZUKA (1975) interpreted the geomorphological features in the region as an effect of the northward shift of the Izu-Bonin Arc by the dragging of the Pacific Plate and purposed that a narrow plate, "the Izu Inner Bar" had moved to the north relative to the Philippine Sea floor. As for the Pre-Miocene bending of Honshu, Matsuda $(1978,1984)$ attributed it to the buoyant subduction of aseismic ridges beneath Central Honshu in the early Tertiary. The triple junction off Central Honshu has been located at its present position relative to Honshu since the Late Miocene. Komazawa et al. (1985) compiled the Bouguer anomaly map around Suruga Bay. SoH (1985) discussed the tectonogeology of the Minobu Group.

The purpose of this paper is to investigate the underground structure of the region based on the measured gravity and magnetotelluric (MT) data, one of the electromagnetic induction techniques (HANDA and Sumromo, 1985). 


\section{The Outline of Geology around the Surveyed Area}

The gravity and magnetotelluric surveyed area is located on the western part of the South Fossa Magna. The geological structure was described by several researchers and groups (Matsuda, 1958, 1961, 1978; Fujigawa Collaborative RESEARCH Group, 1976; NishimIYA and UEDA, 1976; SoH, 1985). In this area, there are so many tectonic lines and faults that the area is divided into several geological blocks, so that it is not easy to make geological interpretations. We have taken our information from the geological description by MATSUDA (1984) and NiSHIMIYA and UEDA (1976), which has just covered the surveyed area.

As shown in Fig. 1, Pre-Miocene terrains sharply convex northward in Central Honshu. It is known that the bend structure is associated with a left-lateral fault on its western wing. The fault trending north-south, located to the west of the Akaishi Mountains, called the Akaishi Tectonic Line, offsets the Cretaceous-Paleogene Shimanto and older terrains by about $60 \mathrm{~km}$. Since Miocene rocks have not been

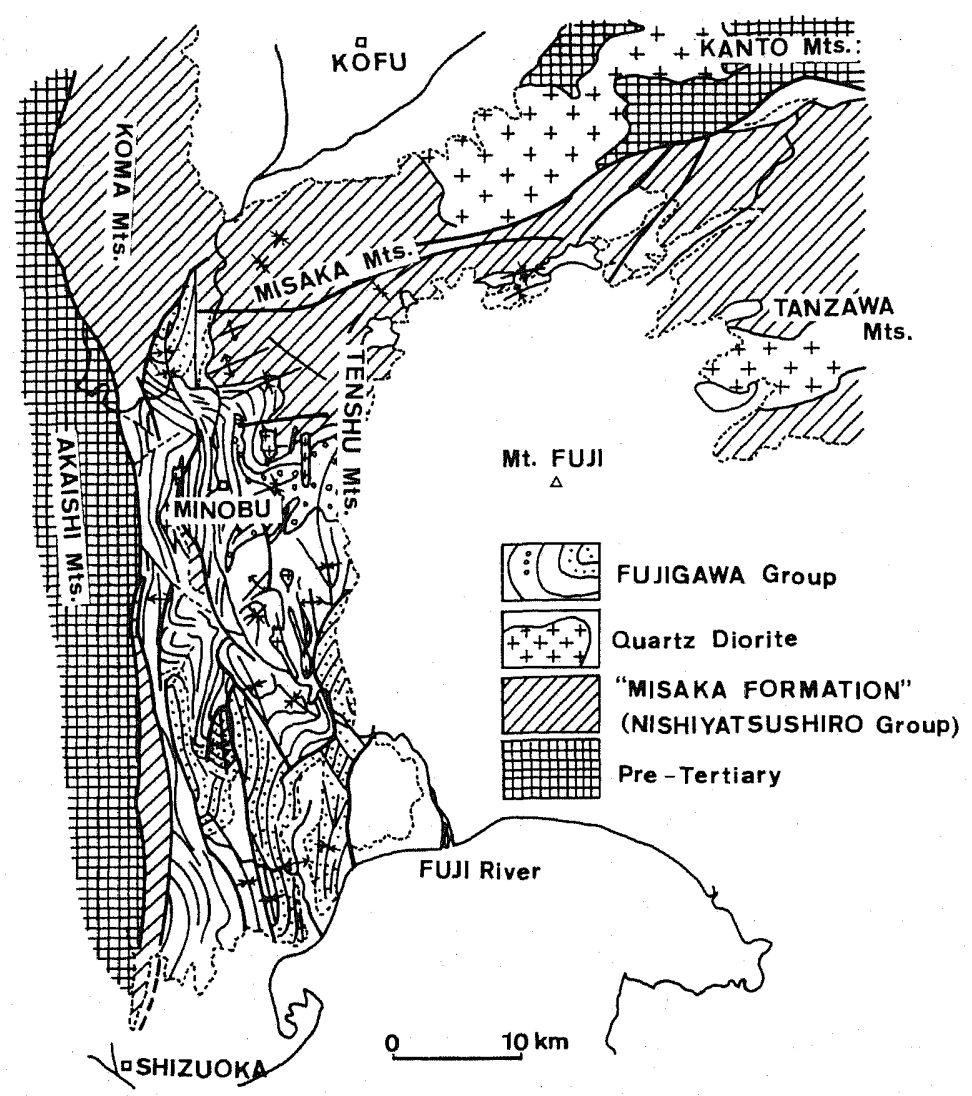

Fig. 1. Geological map around surveyed area (after MATSUDA, 1984). 
subjected to a significant offset by this fault, the faulting took place before Miocene (MATSUDA, 1978).

A Miocene sedimentary zone in the South Fossa Magna, lies on the ocean side of the Shimanto zone, where marine volcanic and clastic sediments more than $10 \mathrm{~km}$ thick were probably deposited on the ocean floor. The rocks in the South Fossa Magna, together with the rocks of the Shimanto zone, have been severely folded, partly overturned, and thrust faulted to form northwest dipping imbricate structures. In this region, the degree of deformation for Miocene rock is the highest among the provinces of Japan. The trend of depositional troughs in this zone and their deformational character are subparallel or slightly oblique to those of the Shimanto zone and form a northward convex arc around Izu Peninsula.

The Minobu formation consists of turbidites which are associated with coarse clastic deposits, such as resedimented conglomerate, pebbly sandstone and massive sandstone. The formation is up to 3,000 $\mathrm{m}$ thick, ranging in age from Late Miocene to Pliocene. The Minobu formation is divided into three major facies associations by SoH (1985). First, the conglomerate association is interpreted as the fills of a single submarine channel system 3-6 km wide. Second, the sandstone association is interpreted as the fills of a network of submarine channels of less than $200 \mathrm{~m}$ in width. Third, the siltstone association is interpreted as interchannel sediments which overflowed from the submarine channel on a slope. Paleocurrent directions indicate fairly constant west-southwest transport and are regarded as being parallel to the paleo-continental slope in this region.

\section{Gravity Measurements}

The gravity survey around the South Fossa Magna was carried out by means of a LaCoste \& Romberg Gravity Meter G-576 during the period of 1984 to 1985. Gravity values were referred to the value of the National Fundamental Station (F.S.) at the Department of Geology and Mineralogy, Kyoto University. The value was redetermined by NAKAGAWA et al. (1970), as 979.70727 gal.

The reference station was occupied at B.M. 82.1 on the surveyed area in order to make the closing time of the loop method as short as possible. After correction from the effect of earth tides and the drift of the gravity meter, the gravity value was determined as 979.69555 gal by the twice loop measurements and its closing error is less than $0.2 \mathrm{mgal}$. The gravity values from the measurements stations were determined by the loop method referred to as the gravity value at the reference station after reduction of the effect of earth tides and the drift of the gravity meter. There were 448 gravity stations in this survey. These gravity stations were situated along the roadsides, as shown in Fig. 2.

The heights above mean sea level of the gravity stations were obtained (i) from the values of the first-order bench marks measured by the Geographical Survey Institute along National Route No. 52, (ii) from the values of the bench marks along Fuji River found by the Kofu Construction Work Office, the Ministry of 


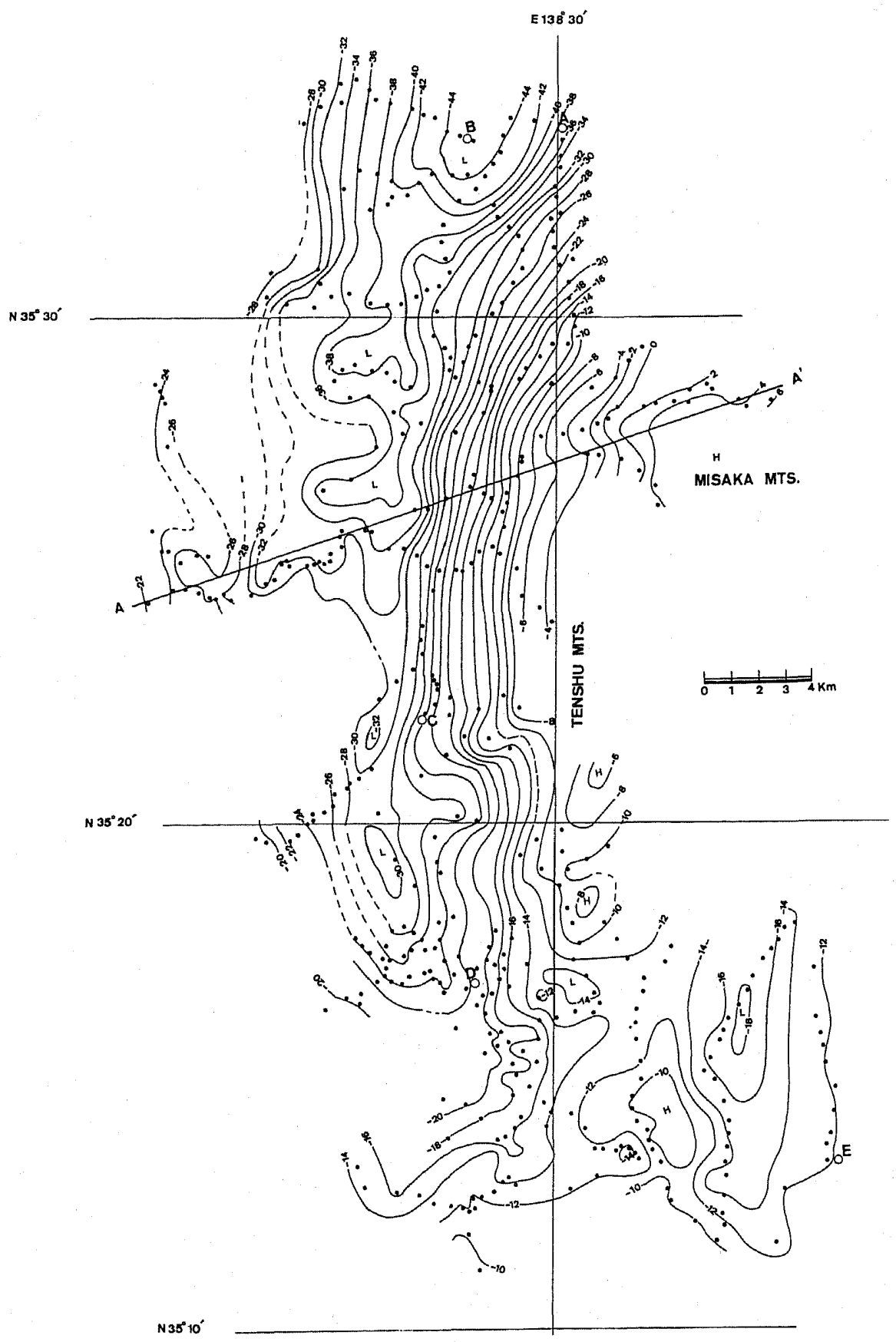

Fig. 2. The distribution of gravity stations $(\bullet)$ and Bouguer anomaly. Assumed density is $2.67 \mathrm{~g} / \mathrm{cm}^{3}$. Contour interval is $2 \mathrm{mgal}$. 
Construction, (iii) from the values of the bench marks along Haya River, a branch of Fuji River, controlled by the Fujigawa Sand Arrestation Work Office, the Ministry of Construction, (iv) from the values of the leveling points along the National Route and Prefecture Routes controlled by Ichikawa and Minobu Construction Work Offices, Yamanashi Prefecture, and (v) from the values of supplemental points measured by two altimeters. It may safely be assumed that the error of height determination relative to reference station B.M. 82.1 is less than 3 and $10 \mathrm{~cm}$ in the case of (i), (ii) and (iii), and of (iv), respectively. The heights of the supplemental points are measured twice, getting there and back using an altimeter Thommen $3 \mathrm{~B} 4 \cdot 01 \cdot 2 \cdot 2500$ and corrected by the values at fixed point measured using an altimeter. The error of height determination is less than $1 \mathrm{~m}$.

The Bouguer anomalies were calculated by adopting the normal vertical gradient of $0.3086 \mathrm{mgal} / \mathrm{m}$ for the free-air reduction and the value of $2.67 \mathrm{~g} / \mathrm{cm}^{3}$ for the Bouguer reduction. Terrain reduction has been calculated by a new program (KATSURA et al., 1986). This calculation was executed using the methods (i) of the numerical integration method and the analytical solution for pentahedrons, using a $250 \mathrm{~m}$ meshed-height of KS-110-1 (Geographical Survey Institute) within the nearest region (KATSURA et al., 1986), (ii) of gravitational attraction of rectangular parallel-pipes within the region of $2 \mathrm{~km}$, using a $250 \mathrm{~m}$ meshed-height (BANERJEE and GUPTU, 1977), (iii) of gravitational attraction by a line-mass concentration along the vertical axis through the center of the prism, using a $250 \mathrm{~m}$ meshed-height of KS-110-1 within $6 \mathrm{~km}$, and (iv) of gravitational attraction by a line-mass concentration along the vertical axis through the center of the prism, using a $1 \mathrm{~km}$ meshed mean height determined from the KS-110-1 within $50 \mathrm{~km}$.

The normal gravity values for each station were calculated with the Normal Gravity Formula 1967, but with a correction for the atmosphere. The geotectonic trend is north-south along the Fuji River, so that the distribution of the gravity stations is dense along the east-west trending roads (Fig. 2).

Figure 3 shows the relationship between $\left(g-\gamma_{0}\right)$ and $H$ in the surveyed area, where $g$ is the measured gravity value, $\gamma_{0}$ is normal gravity value at sea level and $H$ is the altitude of the gravity station. As the slope of the points determined by the least squares method in this figure is proportional to $(-0.3086+0.0419 \rho)$, the average density $\rho$, of the surveyed area can be calculated as $3.1 \mathrm{~g} / \mathrm{cm}^{3}$. Using the same method, the densities of the Misaka, Fujigawa, and Setogawa Groups were obtained as $3.5,1.8$, and $2.7 \mathrm{~g} / \mathrm{cm}^{3}$, respectively, but the densities of rock samples were obtained as shown in Table 1 . The difference of these densities are considered to be due to the tectonic underground structures.

A large low Bouguer anomaly is suspected to occur along the west side of the Fuji River with north-south trending from Kofu Basin to Nambu-Cho (Fig. 2). KONO et al. (1982) measured and compiled the gravity anomalies around Kofu Basin as shown in Fig. 4. As shown in this figure, the trend of low gravity anomaly runs from north to south, that is from Nambu-Cho to the southwestern side of Kofu Basin and turns east along the southern side of Kofu Basin. KomAzAwA et al. 


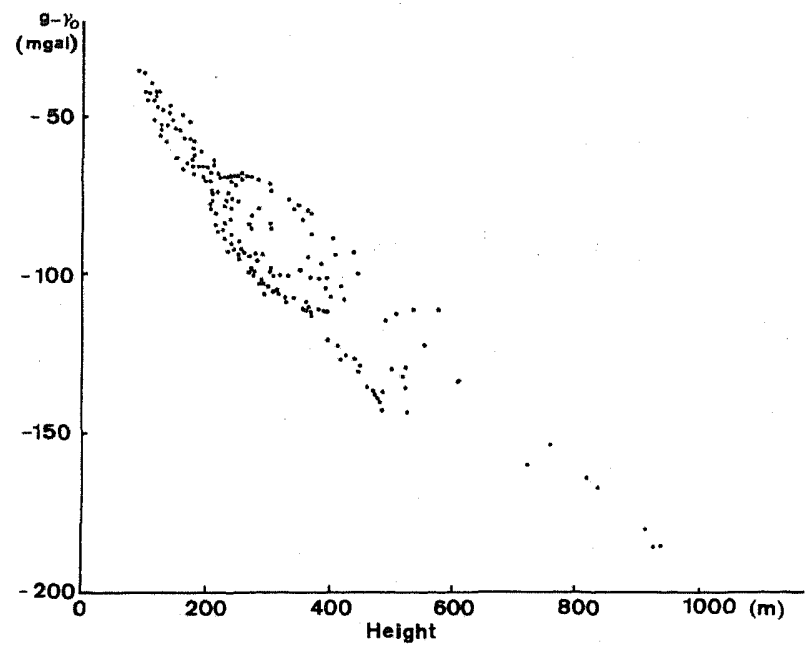

Fig. 3. $\left(g-\gamma_{0}\right)-H$ relation.

Table 1. Density of rock specimens collected from surveyed area.

\begin{tabular}{lcc}
\hline Rock type & Nos. of samples & $\begin{array}{c}\text { Density } \\
\left(\mathrm{g} / \mathrm{cm}^{3}\right)\end{array}$ \\
\hline $\begin{array}{l}\text { Nishiyatsushiro Group } \\
\text { Tuffaceous sandstone }\end{array}$ & 2 & 2.68 \\
$\quad$ Tuff & 2 & 2.55 \\
Fujigawa Group & & \\
$\quad$ Sandstone & 3 & 2.59 \\
$\quad$ Mudstone & 3 & 2.63 \\
$\quad$ Sandstone & 2 & 2.55 \\
Setogawa, Group & 3 & 2.72 \\
Shale & & \\
\hline
\end{tabular}

(1985) carried out a gravimetric survey in the coastal area around Suruga Bay, and made a numerical compilation with the data obtained by Teikoku Oil Co., which is shown in Fig. 5. From these three anomaly maps mentioned above (Figs. 2, 4, and 5), we found out a similar low anomaly pattern with a south-north trend from the north side of Suruga Trough, turning east at the west side of Mt. Fuji.

We are currently investigating a number of subcrustal density models by comparing their computed gravity profiles with the measured gravity data. The computer program is based on a two-dimensional array of horizontal rods in cross sections (TALWANI et al., 1959). The density of an individual rod can be changed at will and the new profile computed rapidly.

The profile selected for computer modeling is shown in $\mathbf{A}-\mathbf{A}^{\prime}$ in Fig. 2, and is also shown in Fig. 6. The profile consists of two segments: One over the Misaka 


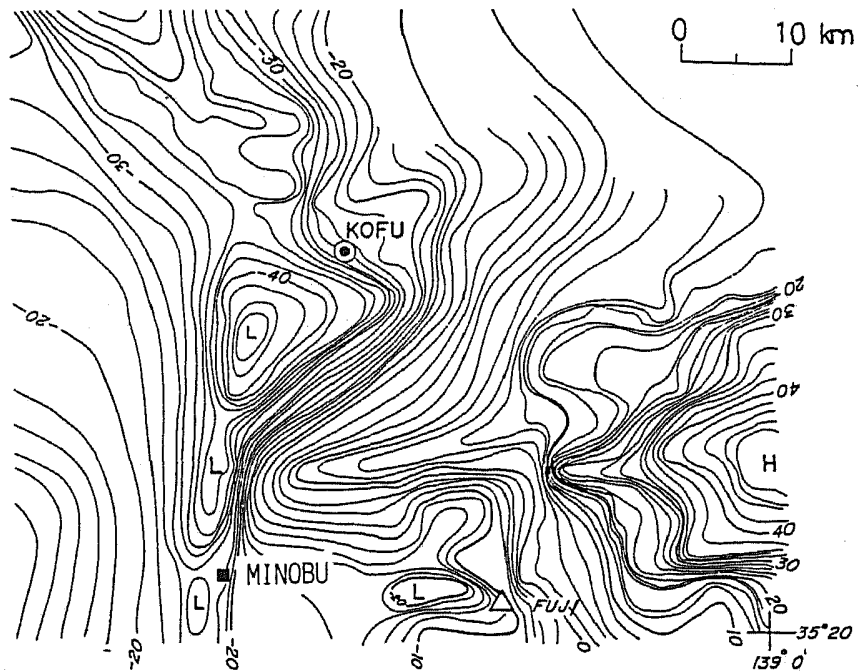

Fig. 4. Bouguer anomaly map of Kofu Basin compiled by Kono et al. (1982). Assumed density is $2.67 \mathrm{~g} / \mathrm{cm}^{3}$. Contour interval is $2 \mathrm{mgal}$.

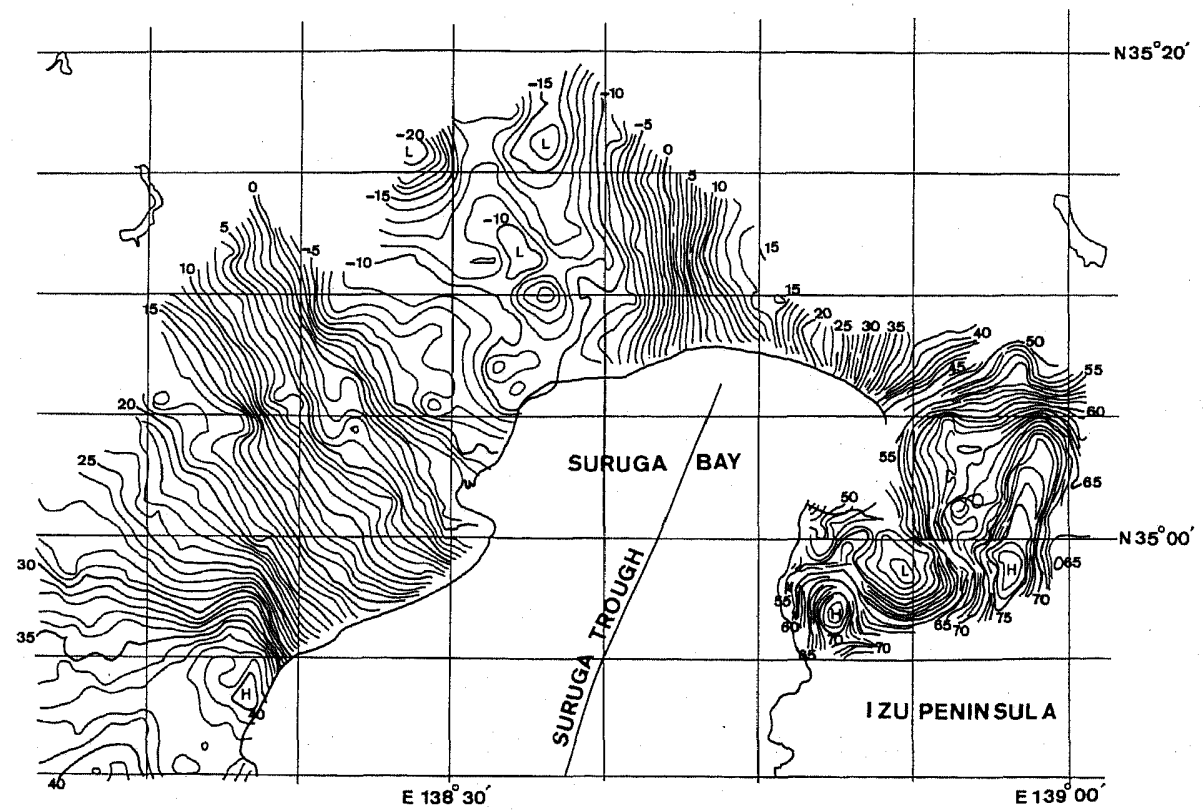

Fig. 5. Bouguer anomaly map around Suruga Bay modified from KomazaWA et al. (1985). Assumed density is $2.67 \mathrm{~g} / \mathrm{cm}^{3}$. Contour interval is $1 \mathrm{mgal}$.

Group (Fig. 1) between Lake Motosu and the Fuji River and the other over the Fujigawa and Misaka Groups (Fig. 1) between Fuji River and the ItoigawaShizuoka Tectonic Line. The main features of the profile are a steep gradient over 


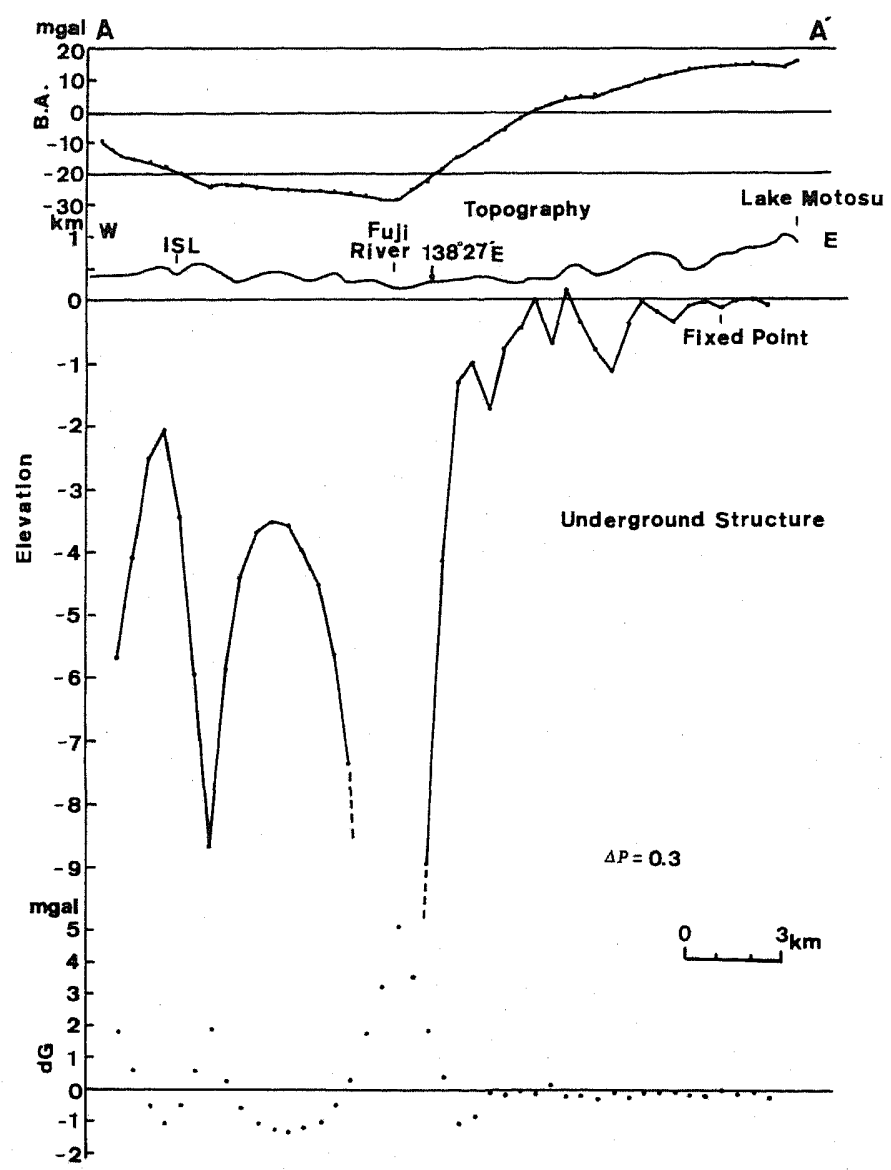

Fig. 6. Computed profile model 1 along $A-\mathrm{A}^{\prime}$ section in Fig. 2. B.A., measured Bouguer anomaly. Solid circle indicates measured Bouguer anomaly value read from Fig. 2; dG, difference between calculated Bouguer anomaly and measured one.

the western segment, the gravity minimum of -29 mgal over Fuji River and a gradual rise over the eastern segment.

As the trend of the Bouguer anomaly pattern continued to the north, it was assumed that the underground structure also continued to the north. An extremely low Bouguer anomaly field exists along Fuji River, so that regional anomaly is not taken into account in this case.

It is clearly necessary to obtain seismic-refraction data to control the choice of densities and depth estimates of the various interfaces needed for accurate modeling. Until such data as are available, the safest approach is to restrict the modeling experiments to a simple model.

First, we restricted the choice of the density difference, $\Delta \rho$, to $0.3 \mathrm{~g} / \mathrm{cm}^{3}$, 


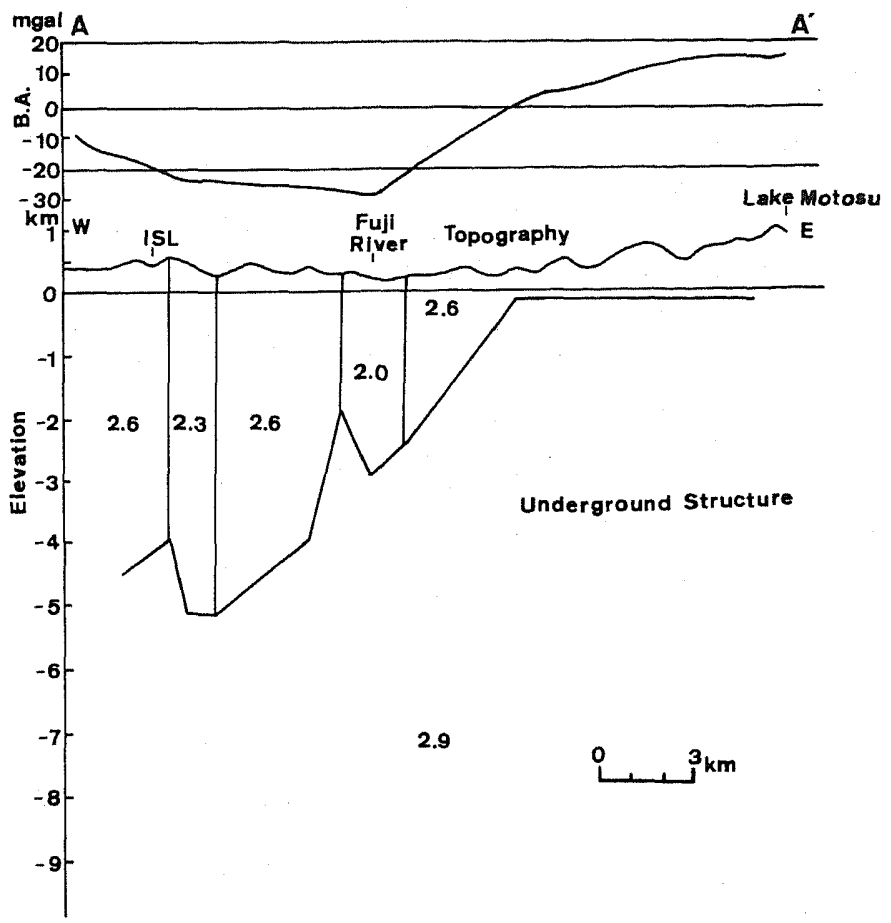

Fig. 7. Computed profile model 2 along $A-A^{\prime}$ in Fig. 2. Symbols are the same as those in Fig. 6.

between the lower crust and the upper crust, using observed densities (Table 1). The known depth of thickness of the upper crust is fixed as shown at one point in Fig. 6, using the data of the ELF-MT method, mentioned later. From these conditions, an approximate estimate of the thickness of the upper crust is made along the entire profile by the Talwani method (TALWANI et al., 1959) as shown in Fig. 6.

A comparison between the computed Bouguer anomalies and measured anomalies is shown in this figure. The difference between these two values is over $2 \mathrm{mgal}$ in some parts of this profile (Fig. 6). There is no close agreement between computed and measured anomalies. This difference is over 2 mgal at almost all points. Consequently, we assumed, as a second model, a vertical contrast model as shown in Fig. 7. In this profile, the difference between computed and measured anomalies shows close agreement except for some border points estimating the difference of the density. There are two main features of this model; the sedimentary basin has a steep slope from the eastern part of this profile until the ItoigawaShizuoka Tectonic Line. The big crushed zones along Fuji River as well as the Itoigawa-Shizuoka Tectonic Line demonstrate the second feature. 


\section{ELF-MT Survey}

The ELF-MT (magnetotelluric) system, which is almost the same as Handa's apparatus (HANDA and SUMITOMO, 1985), used in this study consists of a magnetometer, a telluric amplifier and a voltage meter (Mogr et al., 1985). Telluric and magnetic fields are amplified and selected waves are taken out by hand-pass filters which have peak responses at frequencies of $7.8,14,20 \mathrm{~Hz}$, and also $17.4 \mathrm{kHz}$ (VLF).

The ELF-MT sounding was made at 77 sites which lay along the east-west crossing lines of the faults. The distribution of these sites is shown in Fig. 8. Sounding sites were selected to be located as far as possible from AC power transmission lines. Nevertheless, noise especially in the telluric component was so

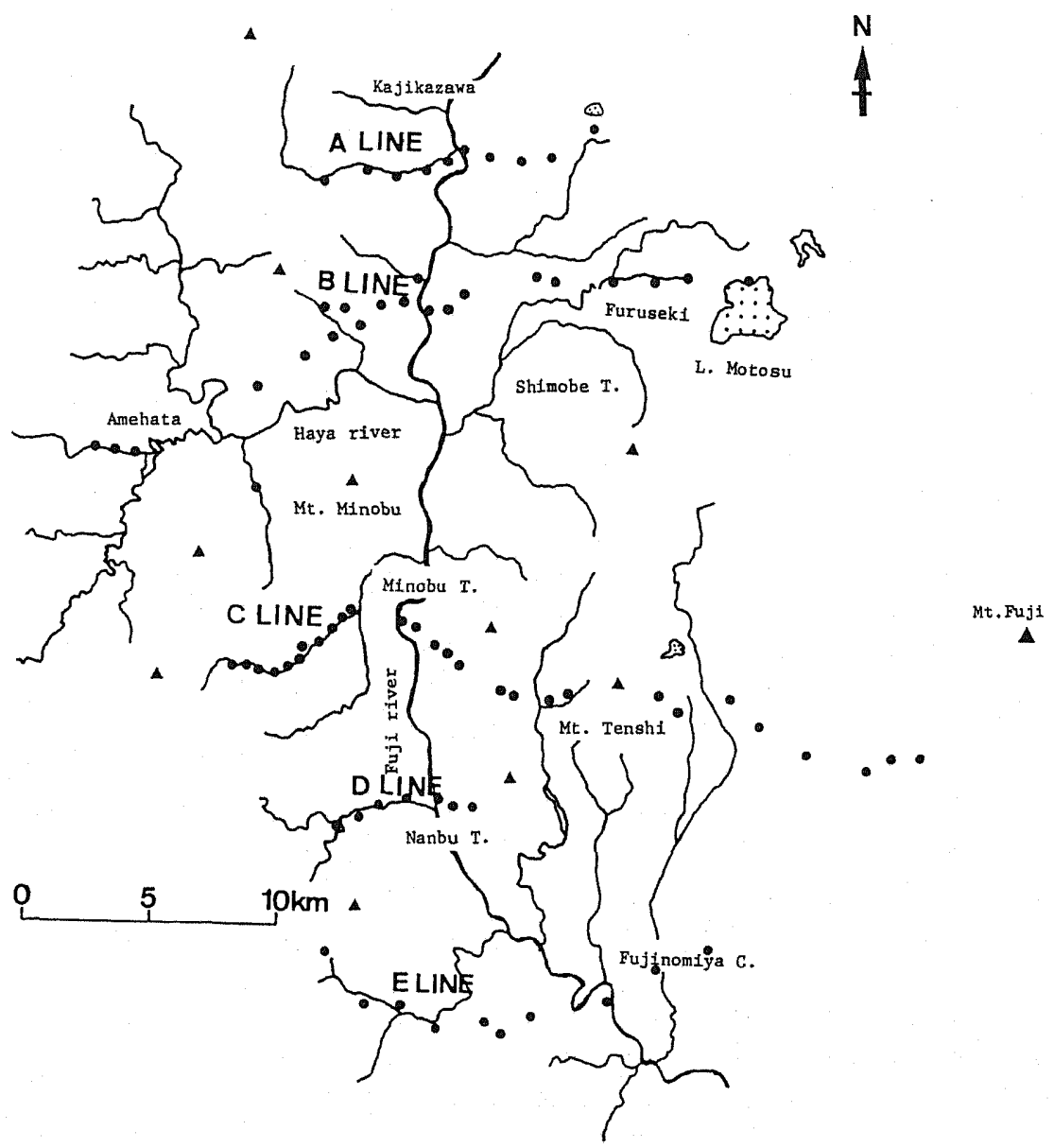

Fig. 8. The distribution of stations measuring earth resistivity by the magnetotelluric method. 


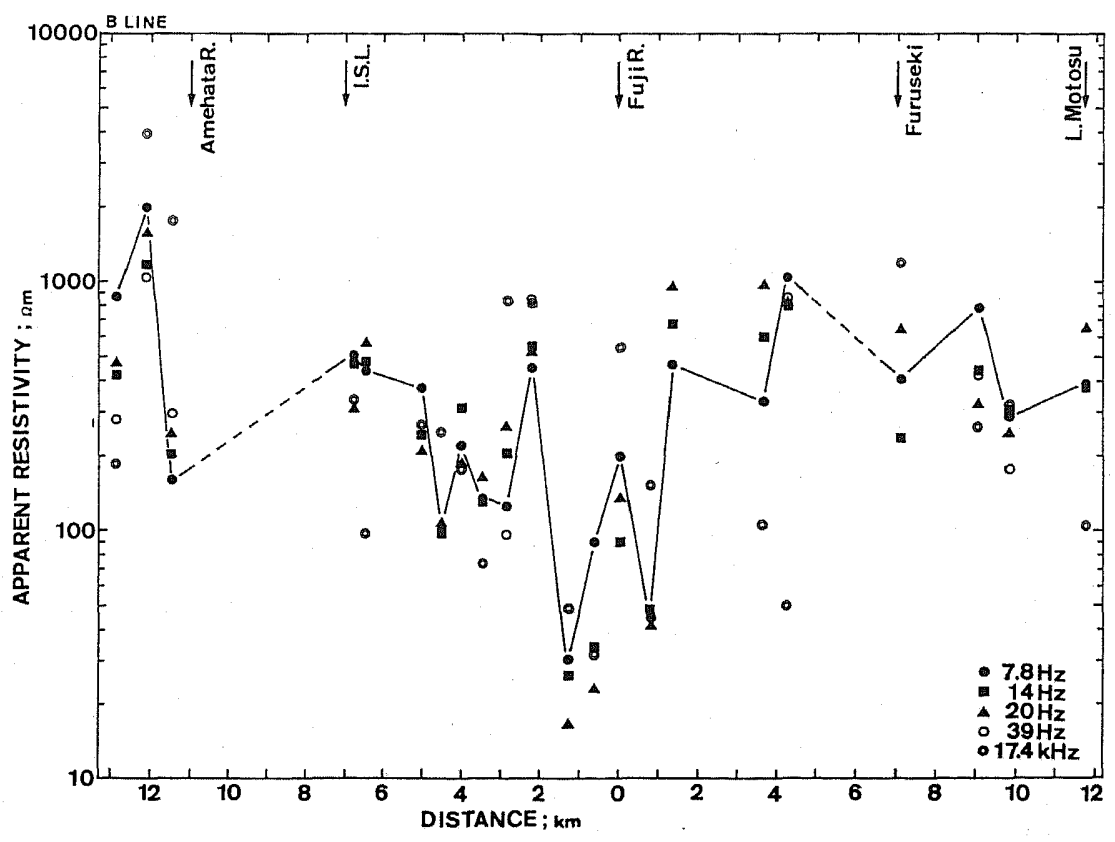

Fig. 9. Apparent resistivity along the B-line in Fig. 8.

loud at a few sounding sites near the main fault axis that observations were difficult. Noise current probably flows at a concentrated level in the highly conductive zone along the main fault axis.

Apparent resistivities for $\mathrm{H}$-polarization (i.e., telluric field is perpendicular to the strike of the discontinuity) obtained at frequencies of $7.8,14,20 \mathrm{~Hz}$, and $17.4 \mathrm{kHz}$ are plotted against the distance from the main fault axis (along Fuji River) as the same profile obtained by gravity anomalies (Fig. 9). The theoretical magnetotelluric response to a two-dimensional resistivity contrast shows that apparent resistivity varies smoothly for E-polarization (i.e., telluric component is parallel to the strike of the discontinuity), but discontinuity exists for $\mathrm{H}$ polarization (e.g., VozofF, 1972).

It is clearly seen in Fig. 9 that the low-resistivity zones with a typical apparent resistivity of about $20-200$ and $100-200 \mathrm{ohm}-\mathrm{m}$ for $7.8 \mathrm{~Hz}$, extend laterally from the Fuji River and also along the Minobu Fault axis, about $2-3 \mathrm{~km}$ towards both sides, respectively. Outside of these zones, apparent resistivities are relatively high, 200-800 and 900-2,000 ohm-m, for the Fujigawa and Misaka Groups and Setogawa Group respectively. The resistivity decrease is very steep at both side boundaries of these zones. Along the Fuji River, the fault zone is not defined on the surface geological survey, but is geophysically defined. This fault is named here as the Fujigawa Dani Fault.

An interpretation is made through two stages as usual (e.g., VozofF, 1972). In 


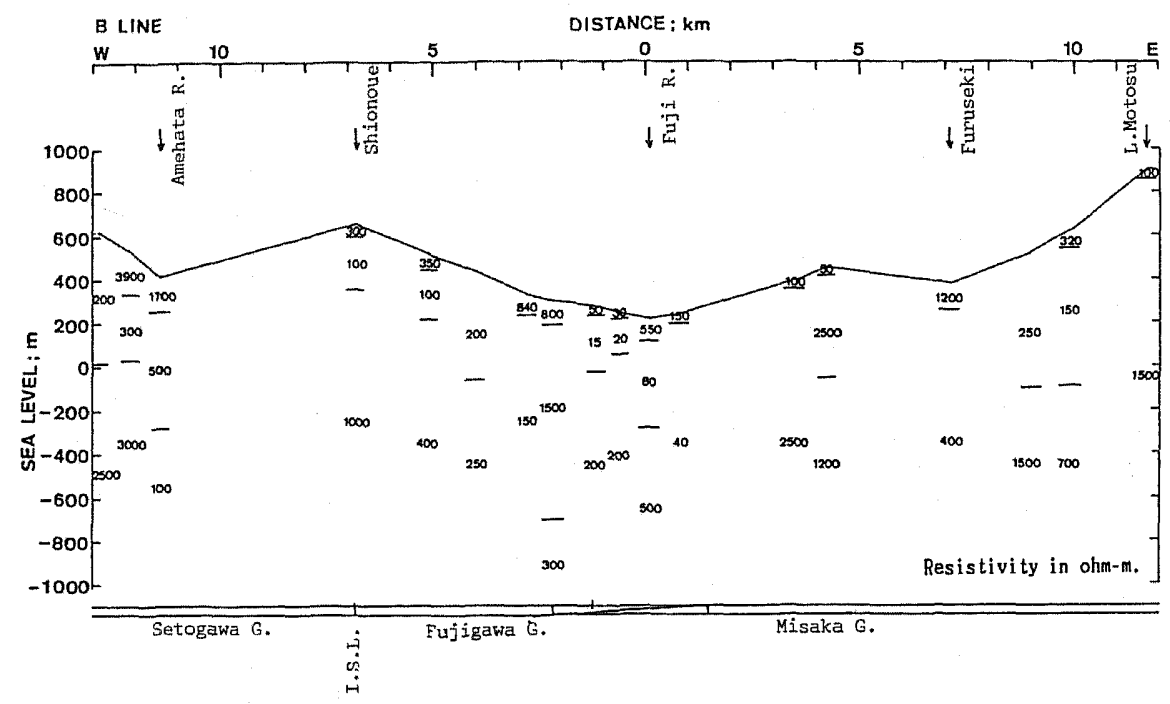

Fig. 10. Computed profile of resistivity along the B-line in Fig. 8.

the first stage, assuming a two- or three-layered model, one-dimensional resistivity distribution is obtained by inversion of the observed apparent resistivity result for each sounding. For this purpose, resistivity and thickness of the topmost layer are determined by the additional $17.4 \mathrm{kHz}$ sounding. Determining the values of the topmost layer is also useful from the standpoint that the H-polarization response is greatly influenced by near-surface resistivity variations.

In the second stage, a two-dimensional inversion process is performed. An initial two-dimensional model is constructed from the one-dimensional models obtained for each site in the first stage, as in Fig. 10. The model explains the observation fairly well. The basic structure of the low-resistivity zone is considered to be the conductive "dike like" body with a resistivity one order of magnitude smaller than the surroundings. However, these zones are rather wide, having a width of about $2-3 \mathrm{~km}$ along the Fuji River (Fujigawa Dani Fault) and Minobu Fault.

Though the resistivity model like Fig. 10 is not unique, it is the most reasonable one in use for the present technique. The low-resistivity zone continues deeper than $1,000 \mathrm{~m}$. Within the low-resistivity zone, some anomalies are found both along the Fujigawa Dani Fault, Minobu Fault and also the Itoigawa-Shizuoka Tectonic Line, where resistivity is much smaller than the surrounding region. They are shown as 40 and $100 \mathrm{ohm}-\mathrm{m}$ area for the eastern part of Fujigawa Dani Fault and for the Minobu Fault, in Fig. 1. They seem to be located just beneath the faults. They may correspond to the "highly localized conductivity anomaly" where it has been concluded that the high conductivity of this anomaly is due to the water saturated clayish minerals. 


\section{Discussion}

The gravity model for the A-A' section, the South Fossa Magna Region (Fig. 7), clearly shows the basement of the $2.9 \mathrm{~g} / \mathrm{cm}^{3}$ layer increasing its depth steeply to the west and the existence of a low-density zone of about $2 \mathrm{~km}$ in width. The former indicates that the eastern plate is declined westward, at an angle less than $40^{\circ}$.

The low-density zones are $2.0 \mathrm{~g} / \mathrm{cm}^{3}$ with a width of about $2 \mathrm{~km}$ along the Fujigawa Dani Fault and there is also a $2.3 \mathrm{~g} / \mathrm{cm}^{3}$ zone of about $1.5 \mathrm{~km}$ in width along the eastern part of the Itoigawa-Shizuoka Tectonic Line.

The resistivity models for section B (Fig. 10) also clearly show the existence of a broad low-resistivity zones of several kilometers along the Fujigawa Dani Fault, Minobu Fault and along the eastern part of the Itoigawa-Shizuoka Tectonic Line. As the resistivity of sedimentary rocks is, in general, lower than that of igneous rocks, the few thousand ohm-m resistivity seems to indicate sedimentary rocks.

From these results, the sedimentary basin is increasing its depth steeply towards the Itoigawa-Shizuoka Tectonic Line. The mean density of these sedimentary rocks is about $2.6 \mathrm{~g} / \mathrm{cm}^{3}$ and the resistivity is about $1,000-2,500 \mathrm{ohm}-\mathrm{m}$. In the upper crust, a high conductive anomaly is caused by water saturation in rocks. An increase in water content decreases resistivity in rocks (PARKHOMEKO, 1967). The main cause of the high-conductivity and low-density is not to be found in the difference in the rock type but in the mechanical property of the fault zone. In other words, it is caused by the fact that rocks are fractured by the fault activity and have become porous. The presence of the wide high-conductivity and low-density zone in the fault strongly reinforces this interpretation. It is concluded that the broad region fractured by fault activities might be filled with water and is detected as the wide high-conductivity zones in this region. It is natural that these fault zones are an ensemble of the zones fractured by several activities of individual faults which constitute an active fault system.

A similar discussion on the "high-conductivity zone in Yamasaki Fault" was done by HANDA and TAMADA (1981) and HANDA and Sumitomo (1985).

Fractures in rocks occur incessantly because of the fault activity while the fault is inactive. However, compressive stress closes fractures, once the fault ceases its activity. Laboratory experients also indicate that resistivity of the rocks saturated with water significantly increases with pressure (e.g., BRACE et al., 1965). Since the electrical conduction in water-saturated rocks takes place through the motion of ions, resistivity of rocks increases when cracks are closed by compressive stress and the conducting paths decrease in cross sections (BRACE et al., 1965). The Fujigawa Dani Fault is supposed to have been active since some time in the Quaternary Period. On the other hand, the Minobu Fault and Itoigawa-Shizuoka Tectonic Line are expected to have been active since the Miocene and Paleogene Periods, respectively. The high-conductive zones in these fault systems may be active now. 


\section{Conclusive Remarks}

The density and resistivity structures of the active faults have been studied in this paper. The extremely low Bouguer anomaly zone is characterized along the Fujigawa Dani Fault, by a strong $4.5 \mathrm{mgal} / \mathrm{km}$ gradient from the east side of the surveyed area. This trend was traced from Kofu Basin to Nambu-Cho. The profile of density distribution was computed using the Bouguer anomalies. From the results, sedimentary basin has a steep slope from the eastern part of the surveyed area and even continues under the Itoigawa-Shizuoka Tectonic Line. The lowdensity and low-resistivity zone, whose density is smaller than $2.3 \mathrm{~g} / \mathrm{cm}^{3}$, has a width of $1.5-2.0 \mathrm{~km}$. The resistivity in this zone is smaller by one order of magnitude when compared with the surrounding area. These fault trends tend to have shifted their position eastward. The low-density and low-resistivity zone is possibly due to rock fractured by the fault activity and is a good indicator of an active fault.

The similar low-gravity anomaly pattern is found at the northern side of Suruga Trough (Kono et al., 1982; KomazAwA et al., 1985), that is, the pattern of trending northward turning eastward. The last activity of Fujigawa Fault was recorded in 1854 at the time of the occurrence of the Ansei Tokai Earthquake ( $M$ 8.4) (TsunEISHI and SHIOSAKA, 1981). Our understanding of active fault systems can be improved significantly by assuming that a collision of the Tanzawa Mountain Block with Central Honshu took place and there was a pushing of it northward. In the same way, the Izu-Block collided with Central Honshu in the Quaternary Period.

We would like to express thanks to the members of the Group for the study of the South Fossa Magna for their useful discussion. We thank Mr. I. Katsura, Mr. A. Ushiki, and Mr. M. Inoue for computer programs of the terrain reduction and for helping with the survey.

\section{REFERENCES}

BANERJEe, B. and S. P. D. GuPTU, Gravitational attraction of rectangular parallel pipes, Geophysics, 42, 1053-1055, 1977.

BRACE, W. F., A. S. ORAnge, and T. R. MAdDEN, The effect of pressure on the electrical resistivity of water-saturated crystalline rocks, J. Geophys. Res., 70, 5669-5678, 1965.

Ehara, S., Geotectonics of the Pacific concerning the Japanese Island. 1. The Fossa Magna, the Shichito and the Ogasawara salients, J. Geol. Soc. Jpn., 59, 173-200, 1953.

Fujigawa Collaborative Research Group, Geological structure of the upper Tertiary in the Upper Fujigawa Valley, Yamanashi Prefecture, Central Japan, Mem. Geol. Soc. Jpn., 13, 329-348, 1976.

Handa, S. and N. Sumitomo, The geoelectric structure of the Yamasaki and Hanaori Faults, Southwest Japan, J. Geomagn. Geoelectr., 37, 93-106, 1985.

HANDA, S. and O. TAMADA, Observation of earth resistivity at the Median Tectonic Line; Application of ELF-MT method to Northeastern Shikoku District, Tsukumo Earth Sci., 16, 1-5, 1981. 
KAIZUKA, S., A tectonic model for the morphology of arc-trench systems, especially for the echelon ridges and mid-arc faults, Jpn. J. Geol. Geocryol., 45, 9-28, 1975.

Katsura, I., J. Nishida, and S. Nishimura, Computed analyses of terrain reduction, ButsuriTanko (Geophys. Explor.), 1986 (in press).

KobayashI, T., The Sakawa orgenic cycle and its bearing on the origin of the Japanese Islands, J. Fac. Sci., Imp. Univ. Tokyo, Sec. 2, 5, 219-578, 1941.

KomaZAWA, M., I. HASEGAWA, and Y. SuDA, On the gravity anomalies in the coastal area around Suruga Bay. (1) Measurement and compilation, Bull. Geol. Surv. Jpn., 36, 53-84, 1985.

Kono, Y., T. Hibi, M. Kubo, O. Michigami, K. Shrbuya, M. Sunami, K. Suzuki, and N. FURUSE, Gravity anomaly over the northern part of Central Japan (1), Sci. Rep., Kanazawa Univ., 27, 71-83, 1982.

MAtsuda, T., Late Tertiary stratigraphy and development of folding in Upper Fuji River Valley, Yamanashi Prefecture, Central Japan, J. Geol. Soc. Jpn., 64, 325-345, 1958.

Matsuda, T., The Miocene stratigraphy of the Fuji River Valley, Central Japan, J. Geol. Soc. Jpn., 67, 79-96, 1961.

Matsuda, T., Collision of the Izu-Bonin Arc with Central Honshu: Cenozoic tectonics of the Fossa Magna, Japan, J. Phys. Earth, 26 Suppl,, S409-S421, 1978.

Matsuda, T., Northward-convex structure in the South Fossa Magna and collision of IzuBlock, Quat. Res., 23, 151-154, 1984.

MATSUDA, T. and S. UyedA, On the Pacific-type orogeny and its model. Extension of the paired belts concept and possible origin of marginal seas, Tectonophysics, 11, 5-27, 1971.

Mogi, T., S. Nishimura, K. Mino, and T. Sadahiro, A tectonic zone in the Northwestern part of Kinki District, Southwest Japan (1). The Yamasaki fault region, J. Seismol. Soc. Jpn., Ser. 2, 38, 57-66, 1985.

Nakagawa, I., M. Satomura, E. Abe, K. Katsura, and S. Nishimura, On the new gravity value at the National Fundamental Station of gravity in Japan, J. Geod. Soc. Jpn., 16, 9$15,1970$.

NishimIYA, K. and Y. UedA, The neogene of Yamanashi Prefecture. Research on the neogene stratigraphy of the Southern Fossa Magna, Central Japan, Mem. Geol. Soc. Jpn., 13, 349-366, 1976.

Parkhomeko, E. I., Electrical Properties of Rocks, Plenum Press, New York, 1967.

$\mathrm{SoH}, \mathrm{W}$., Sedimentary facies and processes of paleosubmarine channels in the Mio-Pliocene Minobu Formation, Fujikawa Group, Central Japan, J. Geol. Soc. Jpn., 91, 87-107, 1985.

TALWANI, M., J. L. Worzel, and M. Landisman, Rapid gravity computations for two dimensional bodies with application to the Mendocino Submarine fracture zone, $J$. Geophys. Res., 64, 49-59, 1959.

Tsuneishi, Y. and K. Shiosaka, Fujikawa fault and Tokai Earthquake, J. Jpn. Soc. Eng. Geol., 22, 52-66, 1981.

VozofF, K., The magnetotelluric method in the exploration of sedimentary basins, Geophysics, 37, 98-141, 1972. 